\title{
Changing the Bed
}

\author{
Beverley Brahic
}

\section{Changer les draps}

Sur le point de quitter pour toujours un lieu qu' elle a partagé, une femme entreprend de changer les draps. Ce faisant, elle se souvient de sa grand-mère qui étendait sa lessive et avait une machineà repasser qu'elle utilisait pour les draps. Aussi d'une inscription qu'elle avait trouvée dans le journal de sa grand-mère au jour correspondant à sa naissance, un jour de février, en Saskatchewan: La lessive a gelé sur la corde à linge. Elle se souvient ensuite des instructions de sa mère qui lui a appris à repasser, tandis qu'au sous-sol, elle fait une dernière fois le repassage. Elle se souvient du bruit que faisait le fer à repasser de sa mère, qui aimait repasser devant une fenêtre panoramique donnant sur la mer. Elle s'interroge sur l'univers de cette mère qui aimait avoir les mains occupées. Estce que ses pensées plongeaient dans le verre brisédes vagues, accompa-gnées par les cris aigus des mouettes qui explorent les détritus, dans le sillage des bateaux qui oscillent vers les îles?

I have locked my suitcase for the last time and stood it at the foot of the stairs. Ten minutes yet to wait-I'll change

the bed-I'll get some sheets that fit around this double mattress to cover up its stains.

In the spare room by her linen close my grandmother kept an ironing machine where she sat to feed in quarto sheets through a mangle, like recycles pages.

On rainy days, she hung her washing overhead 
edge pinned to edge, the items paired or graduated from small to biggest.

"The clothes froze on the line," she wrote in her diary the day I was born in February, in Saskatchewan. At the foot of the their snowbound victory garden even the sluggish river was frozen.

And there was a book I read and re-read (was it "Understood Betsy", or "Anne of Green Gables"?) which starts with the thud of an iron pounding against some woman's kitchen table and that was her pleasure.

Mother taught me to iron shirts; she told me you start with the yoke and end up with the collar. Bedsheets she folded up like letters before she pressed them flat as pie dough, standing in her picture window above the ocean. But did her thoughts

ever plunge to the waves' broken glass, like the shrieks of gulls scavenging scraps in the wake of the ferries plying back and forth to the islands?

I iron in the basement by myself. The furnace rumbles with white noise. I like the way my hands keep busy

smoothing wrinkles into grids, while my mind is free to wander. The bricks? I hardly see them any more.

It's the flat things I like best: napkins, pillowcases, tablecloths and sheets. 
Most stains will go away in bleach.

Before I begin I fold up each sheet, as now I've turned this tip edge down, pleased with the white margin,

the line ruled across the blanket. 